\title{
27
}

\section{Statutory Interpretation and the Critical Role of Soft Law Guidelines in Developing a Coherent Law of Remedies in Australia}

\section{Elise Bant ${ }^{1}$ and Jeannie Paterson ${ }^{2}$}

\section{Introduction}

This chapter considers three particular challenges faced by metalegislation such as the Australian Consumer Law (ACL). ${ }^{3}$ The first is to ensure coherent development of the law both within the legislative regime and also between that regime and the common law context in which it is squarely situated. The second, related challenge is to promote the principled and coherent development of an important legal regime in a context where its beneficiaries are unlikely to pursue their rights in court. This requires the regime effectively to be self-enforcing; directing parties to the appropriate standards of conduct and assisting them to resolve any

\footnotetext{
1 Professor of Law, University of Melbourne.

2 Associate Professor of Law, University of Melbourne.

3 Australian Consumer Law (ACL) contained in Sch 2 of the Competition and Consumer Act 2010 (CCA, formerly the Trade Practices Act 1974 (Cth) (TPA)). See also the equivalent provisions in the Australian Securities and Investments Commission Act 2001 (Cth) Div 2, Corporations Act 2001 (Cth) and the Torrens Statutes.
} 
disputes that develop. A third challenge, which underpins the previous two, is the density and complexity of the legislation. This complexity impedes access to justice objectives and constitutes a significant hurdle to the statute being self-executing to any degree.

The chapter considers these challenges in regard to the remedial provisions responding to misleading conduct and unconscionable conduct under the $A C L$. It proposes two possible responses and also makes a law reform suggestion. First, it models an approach to statutory interpretation that both promotes the protective purpose of the statute and encourages coherent evolution of consumer law within and outside of the statutory context. Second, the chapter considers the potential value of problembased practice notes that model the application of key provisions against standard problem scenarios. Finally, the chapter suggests that an understanding of both the influence of the general context in which the legislation is sited, and the way in which consumers use the legislation to protect their rights, should influence statutory design and drafting.

\section{The Principle of Coherence and Remedies under the $A C L$}

The High Court has recently and repeatedly emphasised the principle of coherence as an overriding criterion in the application and development of the law. ${ }^{4}$ While its precise requirements are yet to be fully charted, the principle likely demands an integrated approach to the analysis and application of statutory and judge-made law. ${ }^{5}$ In the context of consumer protection law, which pervades most commercial and consumer disputes and overlaps considerably with the private law of contract, tort and equity, a major challenge is how to move beyond the traditional 'oil and water' approach to the relationship between general and statutory law. In this context, the principle of coherence entails an enquiry into the extent to

4 Miller v Miller (2002) 242 CLR 446, 454 [15] (French CJ, Gummow, Hayne, Crennan, Keifel and Bell JJ); Equuscorp Pty Ltd v Haxton (2012) 246 CLR 498, 518 [34], 520 [38], 523 [35] (French CJ, Crennan and Kiefel JJ).

5 For example, Mark Leeming, 'Theories and Principles Underlying the Development of the Common Law - The Statutory Elephant in the Room' (2013) 36(3) UNSW Law Journal 1002; Paul Finn, 'Statutes and the Common Law' (1992) 22 University of Western Australia Law Review 7; Paul Finn, 'Statutes and the Common Law: The Continuing Story' in Suzanne Corcoran and Stephen Bottomley (eds), Interpreting Statutes (Federation Press, 2005) 52.

6 Jack Beatson, 'Has the Common Law a Future?' (1997) 56 Cambridge Law Journal 300. 
which cognate principles of general law remedies properly influence the interpretation and operation of remedial consumer protection provisions of the $A C L$ and, conversely, whether the $A C L$ itself exerts a 'gravitational force' on the continuing evolution of those general law principles.

In approaching interpretation and application of the $A C L$, the starting point is that ' $[a]$ nalogy $\ldots$ is a servant not a master'. ${ }^{8}$ Primacy must be given to the words and purpose of the statute. On the other hand, while common law analogies 'are not controlling ... they represent an accumulation of valuable insight and experience which may be useful in applying the Act'. ' This chapter accordingly proposes a model of reasoning that starts with the words of the statute, interpreted in light of its purpose. However, common law and equitable principles and doctrines may then properly be drawn upon where they reflect and promote the aims of the statutory orders and are consistent with the statutory scheme as a whole. The chapter illustrates how this approach may promote a more coherent law of consumer remedies, using as examples the debated nature of loss under s 236 of the $A C L$ and the award of rescission-like relief using a combination of $s 243(\mathrm{a})(\mathrm{c})$ and (d).

\section{A. Section 236: Actions for damages}

The $A C L$ does not define the meaning of 'loss or damage' that may be compensated through statutory damages. By contrast, the general law has developed highly sophisticated understandings of the roles and rationales of different conceptions of loss and damage. It seems highly unlikely that parliament chose these words intending that they should reflect entirely novel meanings, in the absence of any legislative definition. Courts have accordingly turned to the general law concepts of loss and damage for guidance. In that context, ' $[t]$ he task is to select a measure of damages which conforms to the remedial purpose of the statute and to the justice and equity of the case'. ${ }^{10}$ However, courts have vacillated over the relevant analogical source. ${ }^{11}$

\footnotetext{
7 Elise Bant, 'Statute and Common Law: Interaction and Influence in Light of the Principle of Coherence' (2015) 38(1) UNSW Law Journal 362.

8 Marks v GIO Holdings Ltd (1998) 196 CLR 494, 529 [103] (Gummow J).

9 Henville $v$ Walker (2001) 206 CLR 459, 470 [18] (Gleeson CJ).

10 Ibid.

11 Compare Marks v GIO Holdings Ltd (1998) 196 CLR 494 and Murphy v Overton Investments Pty Ltd (2004) 216 CLR 388.
} 
The critical point is to draw upon common law concepts that are consistent with and promote the particular statutory words and their protective purpose. Not all common law conceptions of loss are, on that approach, relevant or appropriate sources of analogy. For example, it is well understood in the law of contract that expectation damages are a form of normative, not factual, loss. ${ }^{12}$ Expectation damages make sense in a context where the normative legal order demands contracts must be performed ${ }^{13}$ and a contract has been breached. A plaintiff's dashed expectation of gain caused by proscribed conduct constitutes 'loss' because the plaintiff not only expected the profit but was entitled to it.

By contrast, s 18 ACL does not require defendants to perform their promises or make true their representations. Rather, it requires that defendants do not engage in misleading or deceptive conduct. It follows that expectation damages are not an appropriate measure of loss in cases of misleading or deceptive conduct.

A more appropriate analogical source for s 236 damages, and one consistently identified by the courts, is the concept of reliance loss familiar from, for example, the tort of deceit. ${ }^{14}$ This measure supports and promotes the language of the statute, which directs courts to consider loss caused by misleading or deceptive conduct. This may require us to examine the plaintiff's changes of position made in reliance on that conduct. ${ }^{15}$ Identifying loss flowing from or caused by acts of reliance is therefore a logical starting point for the statutory enquiry and makes deceit an apt analogical source. Likewise the law of negligent misstatement offers an appropriate source of guidance, a point perhaps under-appreciated in the statutory case law to date. ${ }^{16}$ On this approach, the disappointment of shattered hopes may be compensated as a type of distress damage. ${ }^{17}$

12 L Fuller and R Perdue, 'The Reliance Interest in Contract Damages: 1' (1936) 46 Yale Law Journal 52, 53.

13 Clark v Macourt (2013) 88 ALJR 190, 194 [11] (Hayne J).

14 See Kizbeau Pty Ltd $v$ WG \& B Pty Ltd (1995) 184 CLR 281, 291 (Brennan, Deane, Dawson, Gaudron and McHugh JJ); Kenny \& Good Pty Ltd v MGICA (1992) Ltd (1999) 199 CLR 413, 460-61 [129] (Kirby and Callinan JJ).

15 Note Caffey v Leatt-hayter [No 3] [2013] WASC 348 (20 September 2013) [466]-[476] (Beech J).

16 Elise Bant and Jeannie Paterson, 'Limitations on Defendant Liability for Misleading or Deceptive Conduct under Statute: Some Insights from Negligent Misstatement' in Kit Barker, Ross Grantham and Warren Swan (eds), The Law of Misstatements: 50 Years on from Hedley Byrne v Heller (Bloomsbury, 2015) Ch 7.

17 New South Wales Lotteries Corporation Pty Ltd v Kuzmanovski (2011) 195 FCR 234. Cf Competition and Consumer Act 2010 (Cth)s 137C. 


\section{B. Sections 237-39 and 243: Compensation orders etc.}

Sections 237-239 provide courts with the discretion to make a wide range of creative orders, illustrations of which are set out in $s 243,{ }^{18}$ in response to contraventions of the $A C L$. None of the orders listed in s 243 adopt the language of rescission, nor do they refer to other related general law concepts such as counter-restitution or the requirement of restitutio in integrum. Further, s 237(2) of the ACL makes explicit that the remedial aim of the provisions is compensatory, not restitutionary.

Nonetheless, courts have repeatedly held that these provisions empower them to award rescission-like remedies which require restitution and counter-restitution of benefits transferred pursuant to the impugned transaction. In this context, the equitable remedy of rescission has been a powerful albeit not binding guide to the relevant considerations that inform the making of analogous orders under the provision. ${ }^{19}$

Courts have married the restitutionary nature of rescission with the compensatory purpose of the statutory scheme by emphasising that the conception of loss under s $87 T P A$, the precursor to s $237 A C L$, is much broader than the traditional characterisations of loss the subject of compensation orders in tort and, indeed, those covered by the compensatory provisions in s 82 TPA (now s $236 \mathrm{ACL}$ ). In Demagogue Pty Ltd $v$ Ramensky, Black CJ explained, 'the loss or damage contemplated by s $87(1 \mathrm{~A})$ is not limited to loss or damage in the s 82 [s $236 \mathrm{ACL}$ ] sense but was intended to include the detriment suffered by being bound to a contract unconscionably induced'. ${ }^{20}$ The language and structure of the statute taken as a whole 'emphasises that the phrase "the loss or damage", at least in $s 87$, may be concerned with more than pecuniary recovery as understood in the law of damages in tort' and may extend to entry into contractual obligations as a result of misleading or deceptive conduct. ${ }^{21}$

18 For similar provisions to which this discussion can be extended, see, for example, Australian Securities and Investments Commission Act 2001 (Cth) ss 12GM, 12GNC; Corporations Act 2001 (Cth) s 1325; Contracts Review Act 1980 (NSW) s 7; National Consumer Credit Protection Act 2009 (Cth) ss 179-80.

19 Marks v GIO Australia Holdings Ltd (1998) 196 CLR 494, 535 (Gummow J). See also Tenji v Henneberry \& Associates Pty Ltd (2000) 98 FCR 324, 329-30 [12] (French J).

20 Demagogue Pty Ltd v Ramensky (1992) 39 FCR 31, 33.

21 Ibid. 43 (Gummow J). 
This broad, policy-driven conception of 'loss or damage' under the statute is evident in the orders made by courts effecting statutory rescission. Courts adopt a broad conception of detriment that considers whether the plaintiff would suffer detriment in the absence of, or indeed as a result of, the award. ${ }^{22}$ The focus of the enquiry, as for equitable rescission, seems to be whether it is possible to return the parties to the status quo ante. To that end, courts routinely apply change of position-style considerations to protect rescinding plaintiffs from being placed in a worse position than they occupied prior to the impugned transaction. ${ }^{23}$

This approach strongly echoes the evolving approach taken at general law to the change of position defence in claims for restitution of mistaken payments. ${ }^{24}$ The statute in this context provides a model of analogous principles that can and arguably should be drawn upon by courts seeking to further develop that defence, as well as when exercising the equitable doctrine of rescission. On this approach, the statutory jurisprudence would exert a 'gravitational force' on contested issues such as the proper treatment of non-reliance-based changes of position that may promote more coherent and integrated common law, equitable and statutory principles governing restitutionary liability. ${ }^{25}$

\section{The Potential Role of 'Soft Law' Practice Notes}

There is relatively little case law developing the more nuanced aspects of the remedial regime discussed above. What authority does exist rarely involves consumer-trader disputes, and almost none deals with the remedial responses to unconscionable conduct. This is because relatively few private litigants' claims for relief from proscribed conduct under the $A C L$ reach courts. Many disputes covered by the regime involve modest sums, and the value of the claim will not justify the expense of litigation. Many consumers, and some traders, will lack the resources, confidence or

22 See, for example, Munchies Management Pty Ltd v Belperio (1988) 58 FCR 274, 287-89; Akron Securities Ltd v Iliffe (1997) 41 NSWLR 353, in particular the judgment of Mason P.

23 Munchies Management Pty Ltd v Belperio (1988) 58 FCR 274, 287-89; Akron Securities Ltd v Iliffe (1997) 41 NSWLR 353.

24 Australian Financial Services and Leasing Pty Ltdv Hills Industries Ltd (2014) 253 CLR 560.

25 Cf Vadasz v Pioneer Concrete (1995) 184 CLR 102, 115-16. See further E Bant, 'Rescission, Restitution and Compensation' in S Degeling and J Varuhas (eds), Equitable Compensation and Disgorgement (Hart Publishing, 2017) Ch 13. 
expertise to pursue such claims. Most disputes will be resolved informally, without input by lawyers or judges. If not resolved informally or through mediation, consumer-trader disputes under the $A C L$ will usually be heard in small claims courts and consumer tribunals.

There is a delicate balance to maintain here. While consumers need access to low cost informal mechanisms to help them resolve disputes, if access to justice is not to be illusory, it is critically important that those disputes are resolved in accordance with the rights and responsibilities granted by the statutory regime. It is impossible for the regime to evolve and adapt to new conditions if the complex points of interpretation and principle it raises are not given an opportunity to be considered, analysed and debated as in a manner appropriate to any serious body of law.

In this context, the potential role of soft law guidance is significant. ${ }^{26}$ The style of soft law practice notes envisioned would seek to encapsulate key legal principles in a straightforward and accessible format and then illustrate their operation by reference to a series of simple but realistic examples. ${ }^{27}$ The notes need not be exhaustive: the aim is to provide general guidance on the main rights and liabilities that arise under relevant provisions, accepting that exceptions and distinctions can arise which warrant different outcomes.

The potential attractions of this form of guidance include facilitating access to justice under the statute by enabling consumers and traders to better understand their rights and obligations under the law, and providing guidance to courts, tribunals and other decision-makers so as to promote a coherent, consistent rule of law. Practice notes can readily engage in important remedial enquiries that generally fall outside the enforcement action by a regulator and could serve to support and enforce broader legislative objectives beyond those held by the regulator. Practice notes potentially represent an objective snapshot of the law, drawing on a consensus of the views of invested and disinterested stakeholders alike, reflecting the body of case law and reality of common dispute patterns, to produce a guide to consistent dispute resolution that is not aligned to any particular stakeholder perspective. Courts would retain an important

26 See generally R E Megarry, 'Administrative Quasi-Legislation' (1944) 60 Law Quarterly Review 125; Greg Weeks, 'The Use and Enforcement of Soft Law by Australian Public Authorities' (2014) 42 Federal Law Review 181.

27 For good examples of this style of guide, see 'Guidance on the Consumer Protection (Amendment) Regulations’ (UK Department for Business Innovation and Skills, 2014). 
role in this context by both drawing on the notes as a source of shared conceptions of the operation of the regime and also feeding back into the process, by correcting and rationalising the examples given in the practice notes as required and in light of the broader legal landscape.

\section{Statutory Design and Drafting}

The foregoing discussion demonstrates that the way in which decisionmakers interpret legislation is very much influenced by its structure and terms. We have seen that where the $A C L$ uses language such as 'loss or damage' that echoes general law concepts, courts are encouraged to draw upon those concepts to interpret the legislation. Further, positioning that same phrase within separate sections can allow courts to distinguish its meaning and operation, enabling remedial diversity that promotes the statutory purpose. These are positive outcomes of statutory drafting and design.

However, the complex, convoluted and confusing structure of the $A C L$ presents a major impediment to the orderly development of the law, the expressive role of the $A C L$ and the access to justice objectives referred to above. For example, the $A C L$ often requires users to connect provisions located in quite different sections of the same legislation (e.g. the statutory prohibition against misleading conduct in $s 18$ with the remedial options in ss 236-38 and 243 of the $A C L$ ) or within different legislation (e.g. the apportionment provisions found in $137 \mathrm{~B} C C A$, relevant to liability under the $A C L) .{ }^{28}$ These isolated but connected provisions are challenging to navigate for the legally trained, let alone for the lay stakeholders to whom the legislation is addressed. In this context, shorter and simpler legislation that deliberately invites the sort of interpretive process modelled earlier may be more effective in promoting the statutory purposes than a regime that attempts to be comprehensive.

28 See also Wingecarribee Shire Council v Lehman Brothers Australia Ltd (in liq) [2012] FCA 1028 [947]-[949] (Rares J). 


\section{Conclusion}

This chapter has suggested a method for ensuring a dialogue between the legislative regime and the common law context in which it exists with the aim of promoting the consistent and coherent development of both bodies of law. It has also posited the use of soft law practice notes as a way of promulgating this type of development and thereby promoting access to justice. Finally, it has noted the value of simple statutory design in a context where the statute largely needs to be self-enforcing. These are considerations to bear in mind through the ongoing process of legislative revision and reform. 
This text is taken from New Directions for Law in Australia: Essays in Contemporary Law Reform, edited by Ron Levy, Molly O’Brien, Simon Rice, Pauline Ridge and Margaret Thornton, published 2017 by ANU Press, The Australian National University, Canberra, Australia. 